\title{
KUALITAS NUTRISI AMPAS SAGU HASIL FERMENTASI JAMUR TIRAM PUTIH (Pleurotus ostreatus) DENGAN WAKTU PANEN YANG BERBEDA
}

\author{
Insun Sangadji* \\ Jurusan Peternakan, Fakultas Pertanian, Universitas Pattimura \\ Jl. Ir.M. Putuhena, Kampus Poka, Ambon 97233 \\ *Email: insangadji@gmail.com
}

\begin{abstract}
ABSTRAK
Salah satu cara mengatasi ketersediaan jumlah dan nutrisi pakan ternak adalah dengan mengolah dan memperbaiki nilai nutrisi ampas sagu sebagai limbah lokal yang melimpah lokal yang melimpah dan berpotensi sebagai bahan pakan. Penelitian ini bertujuan untuk mengetahui kualitas ampas sagu hasil fermentasi jamur tiram putih (Pleurotus ostreatus) dengan waktu panen yang berbeda. Metode penelitian menggunakan Rancangan Acak Lengkap dengan 4 perlakuan, yakni kontrol (sampel tanpa fermentasi); belum panen (setelah miselium penuh pada media tumbuh); panen pertama (setelah panen jamur yang pertama pada media tumbuh); dan panen kedua (setelah panen jamur yang kedua pada media tumbuh), masing-masing diulang tiga kali. Perbedaan yang nyata antar perlakuan diuji lanjut menggunakan Beda Nyata Jujur (BNJ). Variabel yang diamati adalah kandungan bahan kering, protein, NDF (Netural Detergent Fiber), ADF (Acid Detergent Fiber), dan lignin. Rata-rata kandungan bahan kering setiap perlakuan adalah 40,08\%, 35,16\%, 28,78\% dan 27,23\% untuk kontrol, belum panen, panen kedua dan panen pertama. Rata-rata kandungan protein setiap perlakuan adalah 5,52\%, 5,33\%, 5,21\% dan 2,05\% untuk belum panen, panen pertama, panen kedua dan kontrol. Rata-rata kandungan NDF setiap perlakuan adalah 55,59\%, $51,21 \%, 48,73 \%$ dan 46,43\% untuk kontrol, belum panen, panen panen pertama dan panen kedua. Rata-rata kandungan ADF setiap perlakuan adalah 46,53\%, 44,57\%, 43,74\% dan 42,13\% untuk kontrol, belum panen, panen kedua dan panen pertama. Rata-rata kandungan lignin setiap perlakuan adalah 5,63\%, 4,37\%, 3,29\% dan 3,2\% untuk kontrol, belum panen, panen kedua dan panen pertama. Berdasarkan kandungan nutrisi, ampas sagu fermentasi pada panen pertama dapat digunakan sebagai pakan ternak. Akan tetapi ampas sagu fermentasi pada panen kedua lebih ekonomis.
\end{abstract}

Kata kunci: Kualitas nutrisi, ampas sagu, fermentasi, Pleurotus ostreatus

\section{THE QUALITY OF SAGO BY-PRODUCT FERMENTED WITH WHITE MUSHROOM (Pleurotus ostreatusi) ON DIFFERENT HARVEST TIME}

\begin{abstract}
Improving local feedstuff which is abundantly available in Maluku Province suh as sago (Metroxylon rumphii) byproduct to be a nutritional feedstuff for live is an innovative way to address the scarcity of nutritious feed for livestock in Maluku. The purpose of this research was arranged into a complete randomized design with four treatments: control (no fermentation), before harvest (after full mycelium), the first harvest, and the second harvest. Each treatment was replicated triple. Least square test was applied to determine the statistical differences among the treatmenst. The observed variables were dry matter, crude protein, Neutral Detergent Fiber (NDF), Acid Detergent Fiber $(\mathrm{ADF})$ and lignin. The result showed that there were significant differences $(\mathrm{P}<0.05)$ on dry matter content, protein content, NDF, ADF and lignin content among treatments. Average dry matter content in each treatment was $40.08 \%, 35.16 \%, 28,78 \%$ and 27,23\% for control, before harvest, the second harvest and the first harvest, respectively. Avarage protein content in each treatment was 5.52\%, 5.33\%, 5.21\% and 2.05\% for before harvest, the first harvest, the second harvest and control, respectively. Avarage NDF content in each treatment was 55.59\%, $51.21 \%, 48.73 \%$ and $46.43 \%$ for control, before harvest, the first harvest and the second harvest, respectively. Average ADF content in each treatment was $46.53 \%, 44.57 \%, 43.74 \%$ and $42.13 \%$ for control, before harvest, the secobd harvest and the first harvest, respectively. Average lignin content in each treatment was 5.63\%,4.37\%, $3.29 \%$ and $3.21 \%$ for control, before harvest, the second harvest and the first harvesst, respectively. Based on nutrient content, it is suggested that fermented sago by-product on the first harvest time can be applied as livestock feedstuff. However, fermented sago by-product on the second harvest time is economical.
\end{abstract}

Key words: Nutritional quality, by-product of sagoo, fermentation, Pleurotus ostreatus 


\section{PENDAHULUAN}

Salah satu kebijakan pemerintah dalam pembangunan bidang peternakan di Indonesia adalah usaha dalam pemenuhan kebutuhan protein hewani. Dalam usaha pengembangan produktivitas ternak, informasi tentang pakan merupakan salah satu faktor yang penting untuk diketahui. Ketersediaan hijauan pakan yang tidak memadai baik kualitas, kuantitas dan berkelanjutan menjadi salah satu kendala dalam pengembangan usaha peternakan (Lasamadi dkk., 2013). Pemanfaatan limbah sebagai bahan pakan ternak merupakan alterntif dalam memenuhi kebutuhan nutrisi bagi ternak. Pemanfaatan limbah sebagai pakan ternak secara umum mempunyai faktor pembatas antara lain kualitas nutrisi yang rendah karena kandungan serat yang tinggi.

Besarnya pemanfaatan limbah sangat tergantung pada potensi limbah baik secara kuantitas maupun kualitasnya. Aspek kuantitas terkait dengan jumlah limbah yang dihasilkan dari suatu proses produksi dan persentase penggunaannya sebagai bahan penyusun ransum. Aspek kualitas lebih ditekankan pada nilai nutrisi yang dapat dimanfaatkan oleh ternak untuk meningkatkan produksi dan produktivitas. Diantara berbagai limbah pertanian yang ada di daerah ini, ampas sagu termasuk salah satu limbah yang melimpah dan berpotensi sebagai bahan pakan.

Indonesia memiliki areal tanaman sagu yang sangat luas, yang diperkirakan mencapai 850.000 ha (Soekarto dan Wijandi, 1983). Sagu merupakan salah satu sumber daya nabati di Indonesia yang mulai akhir tahuntujuh puluhan makin meningkat pemanfaatannya, sebagai akibat dari program pemantapan swasembada pangan nasional dan permintaan akan bahan baku industri dan energi. Maluku yang dikenal sebagai daerah produsen sagu mempunyai limbah dan industri pengolahan tepung sagu yang berlimpah. Potensi sagu di Maluku cukup besar, walaupun pada beberapa wilayah telah terjadi pengalihan status pemanfaatan lahan sagu untuk pemanfaatan lain (Louhenapessy, 1998).

Ampas sagu merupakan limbah yang didapat dari proses pengolahan tepung sagu, dimana dalam proses tersebut diperoleh tepung dan ampas sagu dengan perbandingan 1 : 6 dan rata-rata produksi tepung sagu dari batang sagu adalah $220 \mathrm{~kg}$, dengan demikian ampas sagu yang dihasilkan sekitar $1.320 \mathrm{~kg}$ (Rumahlatu, 1981). Haryanto dan Pangloli (1992) menyatakan bahwa ampas sagu terdiri dari serat-serat empulur yang diperoleh dari hasil pemarutan atau pemerasan isi batang sagu. Ampas sagu dapat digunakan untuk berbagai keperluan, diantaranya sebagai pakan ternak. Ampas sagu mengandung karbohidrat dan bahan organik lainnya, akan tetapi kandungan serat kasarnya tinggi dan proteinnya rendah. Untuk itu perlu diupayakan cara-cara yang dapat meningkatkan nilai gizi dari ampas sagu, salah satunya adalah menggunakan teknik fermentasi.

Fermentasi adalah pengolahan pakan secara biologi menggunakan mikroba baik bakteri maupun jamur (Parisutham et al., 2014; Wan and Li., 2012). Proses fermentasi terbukti dapat meningkatkan kandungan gizi suatu bahan pakan maupun pangan, karena dalam proses ini terjadi perombakan substrat oleh mikroba sehingga terjadi peningkatan nilai gizi yang disumbangkan oleh mikroba itu sendiri. Widodo dkk. (2013) menyatakan bahwa bioteknologi fermentasi mampu meningkatkan zat gizi dari bahan dasar.

Fermentasi dapat dilakukan dengan menggunakan enzim atau mikroba, disesuaikan dengan tujuan fermentasi. Dalam proses fermentasi ampas sagu ini, salah satu mikroba yang dapat digunakan adalah jamur tiram putih (Pleurotus ostreatus). Jamur ini dipilih karena selain dapat dikomsumsi (tidak beracun), Tuomela (2002) juga menyatakan bahwa jamur ini merupakan salah satu jenis mikroba pengurai lignin yang paling efisien yang tersedia di alam dan mempunyai kemampuan untuk mengurai lignin.

Jamur Tiram putih (Pleurotus ostreatus)mampu mendegradasi sejumlah besar jenis substrat lingo selulosa, sehingga menyebabkan jamur ini berperan penting dalam menangani limbah organik. Pleurotus ostreatus telah digunakan untuk mengubah limbah menjadi pakan ternak dan pengaruh-pengaruh menguntungkan lainnya (Darwish et al. 2012).

Jamur tiram putih cenderung mengekresi enzim untuk merombak senyawa yang lebih mudah dirombak terlebih dahulu. Jamur akan mengeluarkan enzin untuk merombak pati terlebih dahulu, sesudah itu akan dilanjutkan dengan senyawa lain yang lebih kompleks. Jamur tiram dalam biokonversi jerami padi diketahui mampu mendegradasi lignin, dan setelah dicobakan pada ternak ternyata dapat meningkatkan kecernaan bahan kering dan bahan organik (Jafari et al, 2007). Selama periode pertumbuhan miselium, miselium jamur tiram putih (Pleurotus ostreatus) lebih mampu untuk mendegrasi lignin. Kemampuan degradasi itu akan berkurang ketika primordia (bakal tubuh buah) mulai berkembang membentuk tubuh buah (Platt dan Hadar, 1983 dalam Sangadji, 2009).

Penelitian yang dilakukan oleh Sangadji (2009) di tempat yang berbeda tela membuktikan bahwa ampas sagu dapat digunakan sebagai media tumbuh jamur tiram putih. Kandungan serat yang terdapat pada ampas sagu mampu menyediakan nutrisi untuk pertumbuhan tubuh buah jarum tiram hingga beberapa waktu panen. Masa inkubasi jamur tiram dimulai dari tumbuhnya miselium sampai muncul tubuh buah dan dipanen. Semakin lama waktu panen, semakin banyak jamur yang dihasilkan sehingga nutrisi substrat lebih banyak digunakan untuk pertumbuhan tubuh buah jamur. Dengan demikian kualitas nutrisi media tumbuh 
akan berbeda untuk setiap waktu panen. Proses fermentasi diharapkan akan merombak struktur jaringan kimia dinding sel, pemutusan ikatan lignosellulosa dan peningkatan protein. Hasil penelitian Noferdiman dkk (2014) membuktikan bahwa penggunaan pleurotus ostreatus dengan lama inkubasi tertentu dapat mempengaruhi kandungan serat kasar dan lignin. Pemanfaatan ampas sagu sebagai bahan media tumbuh jamur tiram putih (Pleorotus ostreatus) melalui fermentasi merupakan salah satu pemecahan masalah penanganan limbah dan sekaligus dapat meningkatkan ketersediaan bahan pakan dalam penyusunan ransum. Berdasarkan uraian diatas telah dilakukan penelitian dengan judul kualitas ampas sagu hasil fermentasi jamur tiram putih (Pleorotus ostreatus) dengan waktu panen yang berbeda.

\section{BAHAN DAN METODE}

Penelitian ini dilaksanakan pada lokasi (1) Laboratorium Nutrisi dan Makanan Ternak Jurusan Peternakan Fakultas Pertanian Unpatti, (2) Rumah Jamur Laboratorium Kimia Dasar Universitas Pattimura, dan (3) Laboratorium Balai Penelitian Ternak Ciawi Bogor.

Alat-alat yang digunakan dalam penelitian ini meliputi plastik ukuran $1 \mathrm{~kg}$ sebagai wadah untuk menaruh media tumbuh jamur, karet gelang untuk mengikat baglog, kertas untuk menutup baglog, lampu spirtus sebagai alat pemanas untuk sterilisasi baglog, autoclave sebagai tempat sterilisasi baglog, timbangan $5 \mathrm{~kg}$ dan timbangan digital unuk menimbang bahan dan sampel, cincin pipa paralon ukuran $5 \mathrm{~cm}$ untuk memudahkan dalam penutupan baglog, botol semprot untuk tempat alkohol, spatula untuk mengeluarkan dan menanam jamur, sendok teh untuk menanam jamur, gelas kimia untuk mengukur air dan tempat bibit jamur sebelum ditanam, baki sebagai wadah untuk meletakkan bahan-bahan, kertas label untuk menulis keterangan pada sampel, masker, gunting/silet, isolasi, botol bekas, cawan petri, lesung porselin, tabung pas LPG, drum, ember, korek api, oven listrik, pena dan buku, perlatan dokumentasi. Bahan-bahan yang digunakan dalam penelitian ini adalah ampas sagu (dari jenis sagu molat), dedak, kapur $\left(\mathrm{CaCO}_{3}\right)$, bibit jamur tiram putih, kapas, spirtus, alkohol, air.

Penelitian ini merupakan eksprimen menggunakan metode rancangan acak lengkap (RAL) dengan 4 perlakuan dan 3 ulangan. Perlakuan yang dicobakan dalam penelitian ini adalah 1) kontrol, yaitu sampel tanpa fermentasi, 2) Belum panen, yaitu setelah miselium penuh pada media tumbuhan, 3) Panen pertama, yaitu setelah panen jamur yaang pertama pada media tumbuh, 4) Panen kedua, yaitu setelah panen jamur yang kedua pada media tumbuh. Peubah yang di amati meliputi bahan kering, protein, neutral detergent fiber (NDF), acid detergent fiber (ADF) dan lignin ampas sagu fermentasi.

Pembuatan media tumbuh jamur tiram putih mengikuti Sangadji (2009) yaitu Ampas sagu (40 persen) ditambahkan dedak (10 persen) dan $\mathrm{CaCO}_{3}(1$ persen). Semua bahan ini dicampur dan ditambahkan air (49 persen). Setelah tercampur rata media ampas sagu dimasukan ke dalam kantong plastik transparan, selanjutnya mulut kantong plastik dimasukan ke dalam cincin paralon dan dilipat keluar kemudian diikat dengan karet galang dan ditutup kertas. Media tersebut disterilisasi basah melalui pengukusan selama 5 jam, kemudian didinginkan dalam ruang isolasi selama 2436 jam. Media steril ditanami dengan bibit jamur dengan cara penaburan inokulum sampai merata diatas permukaan sesuai dosis terbaik $( \pm 5 \mathrm{~g}$ per $0,5 \mathrm{~kg}$ substrat). Langkah ini dilakukan dengan cepat (kantong plastik jangan terlalu lama terbuka) dan seasseptis mungkin di dalam ruangan tertutup. Media yang telah ditanami disimpan (fruktifikasi) pada suhu kamar sampai miselium yang berupa benang-benang putih halus menutupi penuh seluruh substrat. Setelah miselium menutup sempurna, kantung plastik dibuka dan dipindahkan ke tempat agak terang, untuk merangsang pertumbuhan tubuh buah jamur. Agar media selalu lembab dilakukan penyemprotan air 2 atau 3 kali per hari. Pengamatan pertumbuhan jamur dilakukan pada waktu belum panen, panen pertama dan panen kedua. Syarat jamur tiram putih (Pleurotus ostreatus) dapat dipanen, yaitu jamur yang telah mencapai ukuran maksimal, dibiarkan tumbuh satu hari lagi apabila tidak ada perubahan ukuran lagi maka jamur tersebut siap dipanen. Pemanenan dilakukan dengan mencabut jamur sampai akarnya.

Data kandungan nutrisi ampas sagu yang diperoleh dianalis menggunakan metode analisis sidik ragam (Analysis of Variance) dan bila terdapat perbedaan antar perlakuan dilanjutkan dengan uji Duncan Multiple Range Test (DMRT).

Tabel 1. Kandungan bahan kering (\%) ampas sagu hasil fermentasi jamur tiram putih (Pleurotus ostreatus)

\begin{tabular}{ccccc}
\hline Ulangan & \multicolumn{4}{c}{ Waktu panen } \\
\cline { 2 - 4 } & kontrol & Belum Panen & Panen 1 & Panen II \\
\hline 1 & 40,05 & 38,46 & 34,46 & 29,66 \\
2 & 40,11 & 33,20 & 23,22 & 25,65 \\
3 & 40,08 & 33,83 & 24,02 & 31,04 \\
\hline Total & 120,24 & 105,49 & 81,7 & 86,35 \\
\hline Rata-rata & $40,08^{b}$ & $35,16^{a b}$ & $27,23^{a}$ & $28,78^{a}$ \\
\hline
\end{tabular}

Superskrip yang berbeda pada baris yang sama menunjukkan perbedaan yang nyata $(\mathrm{P}<0,05)$ 


\section{HASIL DAN PEMBAHASAN}

\section{Bahan Kering}

Hasil penelitian menunjukkan terjadi penurunan bahan kering selama proses fermentasi. Rata-rata kandungan bahan kering tertinggi adalah pada perlakuan kontrol 40,08 \% diikuti perlakuan belum panen $35,16 \%$, perlakuan panen kedua $28,78 \%$ dan perlakuam panen pertama 27,23\% (Tabel 1). Hasil analisis sidik ragam menunjukkan bahwa perlakuan berpengaruh nyata $(\mathrm{P}<0,05)$ terhadap kandungan bahan kering. Kontrol tidak berbeda nyata dengan belum panen, tetapi berbeda nyata dengan panen pertama dan panen kedua.

Penurunan bahan kering dari belum panen sampai panen kedua diakibatkan oleh jamur tiram putih (Pleurotus ostreatus) mendegradasi nutrien media tumbuh jamur. Pada perlakuan kontrol tidak terjadi proses fermentasi dan pemanenan jamur, sehingga tidak ada pemakaian bahan kering. Pada perlakuan belum panen terjadi penurunan kadar bahan kering tetapi tidak berbeda nyata dengan perlakua kontrol, karena jamur tiram putih (Pleurotus ostreatus) hanya mendegradasi nutrien media untuk pertumbuhan miselium dan pertumbuhan tubuh buah jamur belum terrjadi. Sugiyono (2008) menyatakan bahwa makin lama waktu pemeraman, makin berkurang bahan kering ampas sagu hasil fermentasi oleh karena terjadinya kejenuhan kekurangan oksigen, karbon, nitrogen dan kurangnya substrat sebagai bahan nutrisi.

Perlakuan kontrol berbeda nyata dengan panen pertama dan panen kedua disebabkan karena pada panen pertama dan panen kedua terjadi pembentukan tubuh buah jamur yang mengakibatkan semakin berkurangnya kandungan bahan kering. Hal ini terjadi karena jamur tiram putih (Pleurotus ostreatus) menggunakan nutrien substrat sebagai sumber energi untuk pembentukan tubuh buah.

Semakin lama waktu panen, semakin berkuranganya kandungan bahan kering pada substrat. Berkurangnya bahan kering substrat ditandai dengan ringannya berat baglog setelah panen jamur dan ukuran jamur berbeda pada setiap waktu panen. Waktu yang dibutuhkan untuk belum panen (pembentukan miselium selesai) adalah 30-60 hari setelah tanam, panen pertama adalah 100-141hari setelah tanam, sedangkan pada panen kedua adalah 146-184 hari setelah tanam. Penelitian yang dilakukan oleh Sangadji dkk. (2008), mendapatkan bahwa waktu yang dibutuhkan untuk belum, panen pertama dan panen kedua adalah 30-40 hari setelah tanam, 50-60 hari setelah tanam dan 60-70 hari setelah tanam. Penelitian ini berbeda dengan hasil penelitian yang dilakukan oleh Sangadji dkk (2008), karena dipengaruhi oleh beberapa faktor antara lain kadar serat yang lebih banyak, jumlah sampel yang sedikit dan proses pengambilan sampel.

Jamur yang dipanen pertama kali lebih berat dan lebih besar ukurannya dibanding dengan jamur yang dipanen pada panen kedua (rata-rata berat jamur untuk panen pertama dan panen kedua dari enam buah baglog adalah 46 gr dan 9 gr). Hal ini dikarenakan pada panen pertama masih banyak nutrien yang tersedia untuk digunakan bagi pertumbuhan buah jamur, sedangkan pada panen kedua nutrien yang tersedia telah berkurang sehingga walaupun masih dapat bertumbuh akan tetapi ukuran jamur lebih kecil.

Tabel 2. Kandungan protein (\%) ampas sagu hasil fermentasi jamur tiram putih (Pleurotas ostreatus)

\begin{tabular}{ccccc}
\hline Ulangan & \multicolumn{4}{c}{ Waktu panen } \\
\cline { 2 - 5 } & Kontrol & Belum Panen & Panen I & Panen II \\
\hline 1 & 1,98 & 5,07 & 5,07 & 5,11 \\
2 & 2,06 & 5,66 & 5,66 & 6,23 \\
3 & 2,1 & 5,58 & 5,26 & 15,64 \\
\hline Total & 6,14 & 16,55 & 15,99 & $5,21^{b}$ \\
\hline
\end{tabular}

Superskrip yang berbeda pada baris yang sama menunjukkan perbedaan yang nyata $(\mathrm{P}<0,05)$.

\section{Protein}

Rata-rata kandungan protein tertinggi adalah pada perlakuan belum panen $5,52 \%$, diikuti perlakuan panen pertama 5,33\%, perlakuan panen kedua 5,21\% dan perlakuan kontrol 2,05 \% (Tabel 2). Hasil analisis sidik ragam menunjukkan perlakuan berpengaruh nyata $(\mathrm{P}<0,05)$ terhadap kandungan protein ampas sagu. Kadar protein pada waktu belum panen tidak berbeda nyata dengan pertama dan panen kedua, tetapi berbeda nayata dengan kontrol. Demikian juga kadar protein pada waktu panen pertama tidak berbeda nyata dengan panen kedua.

Dari hasil diperoleh terlihat adanya peningkatan protein dalam fermentasi ampas sagu menggunakan jamur tiram putih (Pleurotus ostreatus). Peningkatan ini disebabkan karena adanya sintesis protein yang dilakukan jamur tiram putih (Pleurotus ostreatus). Peningkatan protein juga disebabkan karena jamur tiram putih (Pleurotus ostreatus) dapat mengambil nitrogen dari udara. Ginteropa dan Maksianopa (1975) dalam Sangadji (2009), menyatakan jamur tiram putih 
(Pleurotus ostreatus) mempunyai kesanggupan untuk menarik nitrogen. Kemampuan jamur tiram putih (Pleurotus ostreatus) melakukan fermentasi dalam suasana aerob akan mendukung jamur tiram putih (Pleurotus ostreatus) untuk menviksasi nitrogen dari udara bebas.

Setelah pertumbuhan miselium selesai maka protein akan dimanfaatkan untuk pembentukan tubuh buah, sehingga pada protein substrat yang semakin lama terfermentasi semakin berkurang (Tabel 2). Hal ini sesuai dengan Peterson (1989) yang menemukan bahwa setelah pertumbuhan primer selesai, kandungan protein mulai berkurang karena digunakan untuk pertumbuhan tubuh buah jamur. Griffin (1994) menyatakan bahwa fase pertumbuhan jamur terdiri dari 5 fase, yaitu fase pertumbuhan awal, fase eksponesial, fase perlambatan, fase stsioner, dan fase kematian. Fase awal merupakan fase adaptasi dimana fase ini belum tampak adanya pertumbuhan jamur dan fase eksponensial merupakan fase dimana terjadi pembentukan dan perkembangan miselium. Pada fase perlambatan terjadi penurunan pembelahan sel disebabkan mulai terbatasnya nutrien. Semakin lama waktu panen semakin sedikit nutrien yang terdapat dalam substrat. Hal ini karena nutrien lebih banyak digunakan untuk pembentukan tubuh buah. Oleh karena itu, kadar protein mengalami penurunan sampai panen kedua.

Kandungan protein ampas sagu hasil fermentasi jamur tiram putih (Pleurotus ostreatus) pada penelitian ini lebih tinggi dari penelitian yang dilakukan oleh Sangadji (2009). Pada penelitian ini, kandungan protein ampas sagu pada perlakuan belum panen $4,53 \%$, diikuti panen pertama $3,15 \%$, dan panen kedua $2,99 \%$. Hal ini mungkin disebabkan ampas sagu yang digunakan berasal dari lahan yang berbeda. Kandungan nutrisi ampas sagu tergantung, suhu, $\mathrm{pH}$, media tanam (lahan) dan ketinggian tempat.

Tabel 3. Kandungan neutral detergent fiber (\%) ampas sagu hasil fermentasi jamur tiram putih (Pleurotus ostreatus)

\begin{tabular}{ccccc}
\hline Ulangan & \multicolumn{4}{c}{ Waktu Panen } \\
\\
& Kontrol & Blm Panen & Panen I & Panen II \\
\hline 1 & 57,38 & 50,13 & 48,01 & 45,25 \\
2 & 55,24 & 51,40 & 49,35 & 47,55 \\
3 & 54,16 & 52,10 & 48,83 & 46,50 \\
\hline Total & 166,78 & 153,63 & 146,19 & 139,3 \\
\hline Rata-rata & $55,59^{c}$ & $51,21^{b}$ & $48,73^{a b}$ & $46,43^{a}$ \\
\hline
\end{tabular}

Superskrip yang berbeda pada baris yang sama menunjukan perbedaan yang nyata $(\mathrm{P}<0,05)$.

\section{Neutral Detergent Fiber (NDF)}

Rata-rata kandungan NDF yang tertinggi adalah pada perlakuan kontrol 55,59 \%, diikuti perlakuan belum panen $51,21 \%$, perlakuan panen pertama 48,73 $\%$ dan panen kedua $46,43 \%$ yang memperlihatkan semakin lama waktu panen, kandungan NDF semakin menurun (Tabel 3). Hasil analisis sidik ragam menunjukan bahwa perlakuan berpengaruh nyata $(\mathrm{P}<$ $0,05)$ terhadap NDF ampas sagu. Kadar NDF pada perlakuan kontrol berbeda nyata dengan perlakuan belum panen, panen pertama dan panen kedua. Perlakuan belum panen tidak berbeda nyata dengan panen pertama, tetapi berbeda nyata dengan panen kedua.

Neutral Detergent Fiber atau NDF terdiri atas selulosa, hemiselulosa dan lignin. Dari hasil penelitian yang diperoleh terbukti jamur tiram putih (Pleurotus ostreatus) mampu mendegradasi NDF, dimana tingkat degradasinya berbeda antar perlakuan. Degradasi NDF dimulai sejak pembentukan miselium selesai hingga panen kedua. Kandungan nutrisi media pada perlakuan belum panen masih banyak karena jamur tiram (Pleurotus ostreatus) hanya mendegrasi nutrien media untuk pertumbuhan miselium, sedangkan pada perlakuan panen pertama dan panen kedua kandungan nutrisi dalam media lebih banyak yang digunakan untuk pembentukan tubuh buah. Jamur yang dipanen pada waktu panen pertama lebih besar dari jamur yang dipanen pada waktu kedua. Rata-rata berat jamur pada panen pertama dan panen kedua dari enam buah baglog berturut-turut adalah 46 gr dan 9 gr. Dengan demikian dapat dikatakan bahwa kandungan NDF pada ampas sagu digunakan oleh jamur tiram putih untuk petumbuhan tubuh buahnya, sehingga kandungan NDF pada ampas sagu hasil fermentasi mengalami penurunan dari sebelum difermentasi. Hasil yang sama juga ditunjukkan oleh penelitian Amin dkk. (2015) pada jerami padi yang diberi perlakuan biologi dengan fermentasi serta perlakuan kimia dengan ammonia mampu menurunkan nilai NDF, ADF, selulosa dan lignin.

\section{Acid Detergent Fiber (ADF)}

Rata-rata kandungan ADF tertinggi adalah pada perlakuan kontrol 46,53 \%, diikuti belum panen 44,57 $\%$, perlakuan panen kedua $43,74 \%$, dan perlakuan panen pertama $42,13 \%$ (Tabel 4). Hasil analisis sidik ragam menunjukkan bahwa perlakuan berpengaruh nyata $(\mathrm{P}<0,05)$ terhadap ADF ampas sagu. Kadar ADF pada perlakuan kontrol tidak berbeda nyata dengan belum panen dan panen kedua, tetapi berbeda nyata dengan panen pertama. Perlakuan belum panen tidak berbeda nyata dengan panen pertama dan panen 
kedua. Demikian juga panen pertama tidak berbeda nyata dengan panen kedua.

Acid Detergent Fiber atau ADF terdiri atas selulosa dan lignin. Ternak ruminansia memanfaatkan selulosa sebagai sumber energi utama dalam menyokong pertumbuhan, produksi dan reproduksi. Selulosa merupakan komponen utama penyusunan dinding sel tanaman dan hampir tidak pernah ditemui dalam keadaan murni di alam, melainkan berikatan dengan bahan lain, yaitu lignin dan hemiselulosa membentuk suatu lignoselulosa (Lynd et al., 2002).

Kadar ADF terendah adalah pada perlakuan panen pertama 42,13\%, kemudian panen kedua 43,74 $\%$ dan terakhir perlakuan belum panen 44,57\%. Kandungan ADF pada panen pertama lebih rendah dari kandungan ADF pada rumput gajah yaitu 47,18\% (Ukanwoko and Igwe, 2012) dan hampir sama dengan kandungan ADF rumput gajah hasil penelitian Muhakka dkk. (2014) yaitu 42,62 \%. Dengan demikian dapat dikatakan bahwa kandungan ADF hasil fermentasi pleurotus ostreatuslebih rendah dari rumput unggul, sehingga hasil fermentasi ampas sagu ini dapat digunakan sebagai pakan ternak. Degradasi ADF berhubungan dengan kandungan NDF (Neutral Detergent Fiber) dan degradasi terhadap hemiselulosa, karena kadar ADF merupakan selisih dari NDF dan hemiselulosa (Van Soest, 1963). Penurunan kandungan NDF dan ADF membuktikan bahwa jamur tiram putih (Pleurotus ostreatus) mampu memutuskan ikatanikatan lignohemilelulosa dan lignoselulosa. Jamur tiram putih (Pleurotus ostreatus) menggunakan hemiselulosa, selulosa dan lignin sebagai sumber karbon dan energi. Hal ini menyebabkan jumlah material yang dapat larut dalam sel meningkat dan pada gilirannya sebagai akibat dari penguraian, struktur ampas sagu menjadi empuk dibandingkan sebelum fermentasi.

Tabel 4. Kandungan acid detergent fiber (\%) ampas sagu hasil permentaasi jamur tiram putih (Pleurotus ostreatus)

\begin{tabular}{ccccc}
\hline Ulangan & \multicolumn{2}{c}{ Waktu Panen } & Panen II \\
& Kontrol & Blm Panen & Panen I & 43,39 \\
2 & 48,24 & 43,27 & 43,1 & 45,38 \\
3 & 45,25 & 46,2 & 41,16 & 42,45 \\
\hline Total & 46,10 & 44,25 & 42,12 & 131,22 \\
\hline Rata-rata & 139,59 & 133,72 & 126,38 & $43,74^{a b}$ \\
\hline
\end{tabular}

Superskrip yang berbeda pada baris yang sama menunjukan perbedaan yang nyata $(\mathrm{P}<0,05)$.

Tabel 5. Kandungan lignin (\%) ampas sagu hasil fermentasi jamur tiram putih (Pleurotus ostreatus)

\begin{tabular}{ccccc}
\hline Ulangan & \multicolumn{2}{c}{ Waktu Panen } \\
& Kontrol & Blm Panen & Panen I & Panen II \\
\hline 1 & 6,55 & 5,08 & 4,01 & 3,22 \\
2 & 5,49 & 4,40 & 3,43 & 2,42 \\
3 & 4,85 & 3,63 & 2,20 & 9,87 \\
\hline Total & 16,89 & 13,11 & 9,63 & $3,29^{a}$ \\
\hline
\end{tabular}

Superskrip yang berbeda pada baris yang sama menunjukan perbedaan yang nyata $(\mathrm{P}<0,05)$.

\section{Lignin}

Kandungan lignin yang tertinggi adalah pada perlakuan kontrol 5,63 \%, diikuti perlakuan belum panen 4,37 \%, perlakuan panen kedua 3,29 \%, dan perlakuan panen pertama 3,21\% (Tabel 5). Hal ini menunjukkan bahwa fermentasi ampas sagu dengan jamur tiram putih (Pleurotus ostreatus) mampu menurunkan kadar lingin. Hasil analisis sidik ragam menunjukkan bahwa perlakuan berpengaruh nyata $(\mathrm{P}<0,05)$ terhadap kandungan lignin ampas sagu. Hal ini membuktikan bahwa jamur tiram putih (Pleurotus ostreatus) mampu mendegradasi lignin karena bersifat lignolitik.

Putusnya ikatan lignin kristalin selulosa memudahkan penetrasi selulase yang dihasilkan mikroba rumen. Dengan putusnya ikatan tersebut, ternak ruminansia dapat lebih mudah dalam mencerna pakan yang awalnya berserat tinggi dan nutrisi yang didapat dari pakan tersebut dapat lebih banyak diserap, karena mikroba rumen tidak lagi membutuhkan banyak energi untuk mendegradasi lignin (komponen serat).

\section{SIMPULAN}

Fermentasi ampas sagu dengan jamur tiram putih (Pleurotus ostreatus) terbukti menurunkan bahan kering, neutral detergent fiber (NDF), acid detergent fiber (ADF) dan lignin, serta meningkatkan kandungan protein. Berdasarkan kandungan nutrisi, kualitas ampas sagu fermentasi yang terbaik untuk digunakan sebagai pakan ternak adalah ampas sagu fermentasi panen pertama karena rendahnya neutral detergant fiber (NDF), acid detergent fiber (ADF) dan lignin serta masih tingginya kandungan bahan kering dan protein 
dibandingkan perlakuan yang lain. Secara ekonomis ampas sagu fermentasi panen kedua lebih baik, dimana komposisi nutrien tidak berbeda nyata dengan ampas sagu fermentasi panen pertama tetapi hasil panen jamur yang diperoleh lebih banyak.

\section{DAFTAR PUSTAKA}

Amin, M., S.D. Hasan, O. Yanuarianto, dan M. Iqbal. 2015. Pengaruh Lama Fermentasi terhadap Kualitas Jerami Padi Amoniasi yang Ditambah Probiotik Bacillus Sp. Jurnal Ilmu dan Teknologi Peternakan Indonesia. 1(1): 8-13.

Darwish, G.A.M.A., A.A. Bakr, and M.M.F. Abdallah. 2012. Nutritional value upgrading of maize stalk by using Pleurotus ostreatus and Saccharomyces cerevisiaein solid state fermentation. Annuals of Agricultural Science. 57(1): 47-51.

Griffin, D. H. 1994. Fungal Physiology. Ed. Ke-2. New York: John Wiley \& Sons.

Haryanto dan Pangloli. 1992. Budidaya Tanaman dan Pengelohan Sagu. Yogyakarta: Kanisius.

Jafari, M.A., A. Nikkhah, A.A. Sadeghi, and M. Chamani. 2007. The effect of Pleurotus spp. fungi on chemical composition and in vitro digestibility of rice straw. J Biol Sci. 10(15): 2460-2464.

Lasamadi, D.R., S.S. Malalantang, Rustandi, dan D.S. Anis. 2013. Pertumbuhan dan perkembangan rumput Gajah Dwarf (Pennisetumpurpureum cv. Mott) yang diberi pupuk organic hasil fermentasi EM4. JurnalZootek. 32(5): 158-171.

Louhenapessy, J. E. 1998. Sagu di Maluku (Harapan dan Tantangan dalam Pembangunan) Disampaikan dalam Seminar Berkala pada Pusat Studi Maluku, Unpatti, Ambon.

Lynd, L. R., P. J. Weimer, W. H. Van Zyl, and I. S. Pretorius. 2002. Microbial Cellulose Utilization: Fundanmentals and Biotechnology. Microbiol. Mol. Biol. Rev. 66 (3): 506-577.

Muhakka, Riswandi, dan A. Irawan. 2014. Pengaruh Pemberian Pupuk Cair terhadap Kandungan NDF, ADF, Kalium, dan Magnesium pada Rumput Gajah Taiwan. Jurnal Peternakan Sriwijaya. 3(1): 47-54.

Noferdiman, H. Syafwan dan Sestilawarti.2014. Dosis Inokulum dan Lama Fermentasi Jamur Pleurotus ostreatus terhadap Kandungan Nutrisi Azolla Microphylla. Jurnal Peternakan. 11(1): 29 - 36.
Parisutham, V.. T,H. Kim, and S.K. Lee. 2014. Feasibilities of Consolidated bioprocessing microbes: from pretreatment to biofuel production. Bioresource Technology. 161: 431-440.

Paterson, A. 1989. Biodegradation of Lignin and Cellulosic Materials. In: Animal Production and Health Division, FAO. Biotechnology for Livestock Production. Plenum Press. $\mathrm{p}$ 245 - 259. New York and London.

Rumahlatu, F. J. 1981. Distribusi dan Potensi Pati Beberapa Sagu (Metroxylon sp) di Daerah Seram Barat. [Karya Ilmiah Tidak Dipublikasi]. Bogor: Fakultas Pertanian/Kehutanan yang Beraafiliasi dengan Fateta IPB.

Sangadji, I. 2009. Mengoptimalkan Pemanfaatan Ampas Sagu Sebagai Pakan Ruminansia Melalui Biofermentasi Dengan Jamur Tiram Putih (Pleurotus ostreatus) dan Amoniasi. [Disertasi]. Bogor: Program pascasarjana Institut Pertanian Bogor.

Sangadji, I., A. Parakkasi, K. Wiryawan, dan B. Haryanto. 2008. Perubahan Nilai Nutrisi Ampas Sagu Selam pada Fase Pertumbuhan Jamur Tiram Putih (Pleurotus ostreatus) yang berbeda. Jurnal Ilmu Ternak. 8(1): 3134

Soekarno, S.T. dan S. Wijandi, 1983. Proyek Pengembangan Sagu Sebagai Sumber Pangan di Indonesia. Jakarta: Biro Koordinasi dan Kebijaksanaan Ilmiah, LIPI.

Sugiyono. 2008. Kadar Protein dan Serat Kasar Ampas Sagu (Metroxylon sp) Terfermentasi dengan Lama Pemeraman yang Berbeda. Jurnal Ilmiah Inkoma. 19(1): 20-28.

Tuomela, M. 2002. Degradation of Lignin and Other ${ }^{14} \mathrm{C}$-labelled Compounds in Compost and Soil with an Emphasis on White-rot fungi. Helsinki: Dep. Appl. Chem. Microbiol. Division of Microbiology, University of Helsinki.

Ukanwoko, A.I. and N.C. Igwe. 2012. Proximate Composition of Some Grass and Legume silages Prepared in a humid Tropical Environment. Int. Res. J. Agric. Sci. Soil Sci. 2(2) : 068-071.

Wan, C., and Y. Li. 2012. Fungal pretreatment of lignocellulosic biomass. BiotechnolAdv. 30(6): 1447-1457.

Widodo, A.R., H. Setiawan, Sudiyono, Sudibya, dan R. Indreswari. 2013. Kecernaan nutrient dan performan puyuh (Coturnix coturnix japonica) jantan yang diberi ampas tahu 
fermentasi dalam ransum. Jurnal Tropical Animal Husbandry. 2 (1): 51-56.
Van Soest, P. J. 1963. Use of Detergent in Analysis of Fibrous Feeds III. The Hand book of Dietary Fiber. New York.

Available online at journal homepage: http://ojs3.unpatti.ac.id/index.php/agrinimal 